\title{
Comparative ecology of the European eel, Anguilla anguilla (L., 1758), in a large Iberian river
}

\author{
José Lino Costa · Isabel Domingos · Carlos A. Assis · Pedro R. Almeida • \\ Francisco Moreira · Eric Feunteun · Maria José Costa
}

Received: 23 June 2006/ Accepted: 17 December 2006/Published online: 2 March 2007

(C) Springer Science+Business Media B.V. 2007

\begin{abstract}
A total of 1,816 eels were sampled in 1988, from seven sampling areas. Four areas were located in brackish water and the remaining three were located in freshwater reaches of the Tagus river basin. Eels were more abundant in the middle estuary and decreased both in the upstream and in the downstream directions, with a predominance of males in higher density areas. Smaller individuals preferred more peripheral
\end{abstract}

J. L. Costa $(\varangle)$. I. Domingos · C. A. Assis .

P. R. Almeida · M. J. Costa

Instituto de Oceanografia, Universidade de Lisboa,

Faculdade de Ciências, Campo Grande, 1749-016

Lisboa, Portugal

e-mail: jlcosta@fc.ul.pt

I. Domingos · C. A. Assis - M. J. Costa

Departamento de Biologia Animal, Universidade de Lisboa, Faculdade de Ciências, Campo Grande,

1749-016 Lisboa, Portugal

P. R. Almeida

Departamento de Biologia, Universidade de Évora,

7002-554 Évora, Portugal

F. Moreira

Centro de Ecologia Aplicada "Professor Baeta

Neves", Instituto Superior de Agronomia, Tapada da

Ajuda, 1349-017 Lisboa, Portugal

E. Feunteun

Institut du Littoral et de l'Environnement, Université de la Rochelle, 5 Perspective de l'Océan, 17071 La

Rochelle, France areas, such as margins and upper reaches in the brackish water zone, and the tributaries of the freshwater habitats. It was assumed that this distribution pattern resulted from three main factors: (i) the dominance of larger specimens; (ii) the need to avoid predators and; (iii) the search for better trophic conditions. The condition of the individuals generally decreased toward the upper reaches, apparently due to a corresponding decrease in feeding intensity. The presence of the Belver dam in the main river, $158 \mathrm{~km}$ upstream from the sea, seemed to impose major alterations to the described patterns. The concentration of specimens below this impassable obstacle yielded a reduction in the proportion of females and a decrease in the condition and survival of the eels, contributing to a reduction in the spawning success of this population. Suggestions to diminish the effects of the dam, and to preserve the fishery are also presented.

Keywords Tagus River - Brackish and freshwater - Abundance - Population structure . Feeding and condition - Dam impacts

\section{Introduction}

The European eel, Anguilla anguilla (L., 1758), is a catadromous fish species with a high-economic value (Domingos 2003). Once abundant all over 
Western Europe, this species has suffered an overall decline since the 1980 s, with a recruitment decrease to about $1 \%$ of the former levels after 2000 (Dekker 2003). Marine causes, such as Gulf Stream shifts are thought to reduce the survival of leptocephali larvae during their transoceanic migration, but inland causes (i.e., overfishing of all continental stages, obstructions to migration, habitat loss, decrease of water quality, xenobiotic, and parasite contamination) are also suspected. The combination of marine and inland factors contributes to the reduction of the quality and the number of spawners moving from inland waters to the sea (Feunteun 2002).

In spite of its commercial importance and population decline, data on A. anguilla, in Portugal, is scarce. Until the late 1980s the only studies on eel ecology in this country were conducted in the beginning of the twentieth century by Gandolfi-Hornyold (1916a, b, 1918). More recently a few studies were performed on glass eel migrations (e.g., Weber 1986; Domingos 1992, 2002; Antunes 1994; Bessa and Castro 1994) and on the age and growth (Gordo and Jorge 1991; Domingos 2003), feeding ecology (Costa et al. 1992b, 1993), and distribution and abundance (Costa et al. 1992a, 1993; Domingos 2003; Domingos et al. 2006) of yellow eels. However, research in Portuguese ecosystems does not yet allow for an in-depth understanding of the particular aspects of the species' ecology in a reliable management and protection of the population.

In other countries, a large number of studies on the distribution, abundance, population structure, growth, feeding, and other ecological aspects of yellow eels have been developed, not only for $A$. anguilla (e.g., Sinha and Jones 1966; Neveu 1981; Fernández-Delgado et al. 1989; Laffaille et al. 2003) but also for other anguillids (e.g., Sloane 1984; Smogor et al. 1995; Tzeng et al. 1995). However, most works were conducted either in freshwater or in brackish water, and therefore only few attempts were made to compare the species ecology in both types of ecosystems (Tesch 1977; Helfman et al. 1984; Costa et al. 1993; Domingos 2003; Morrison and Secor 2004). This situation results from the logistical difficulties involved in covering such large areas and/or the methodological constraints related to the need to use different sampling procedures in each environment.

Separate and partial analyses of anguillid populations prevent a global understanding of their ecology, especially for important rivers with large estuaries. Therefore, the development of ecological studies on $A$. anguilla and other anguillids, which include the entire colonized river basin is necessary to understand their responses to different environmental constraints met during the continental phase, including the identification of the factors which influence the settlement of the recruits, the structure of the population and the feeding and growth of the individuals in each type of habitat.

This work represents a contribution to an integrated analysis of the ecology of the yellowphase of $A$. anguilla in a large river basin from the river mouth up to the first impassable barrier to the migration. Another objective of the work is to improve the scientific knowledge of the species ecology in Portugal and, by extension, in the southern region of its distribution range. With that purpose the Tagus eel population was studied in terms of abundance, size structure, sex ratio, feeding activity, and condition of individuals, to detect spatial patterns of variation on those characteristics and to identify the main factors responsible for such variability.

\section{Materials and methods}

Study area

This investigation was conducted in the Tagus river basin, the largest in Portugal and one of the most important of the Iberian Peninsula. This catchment extends over $80,700 \mathrm{~km}^{2}$, of which $31 \%$ belongs to Portugal and $69 \%$ belongs to Spain (Fig. 1). The main river rises in east-central Spain and flows west across Spain and Portugal where it empties in the Atlantic Ocean near Lisbon.

In the Tagus river basin there are countless sources of pollution, namely of agricultural, industrial, tourist and urban origins, in some cases without adequate treatment (Bettencourt et al. 2003). Illegal fishing, modifications of the 


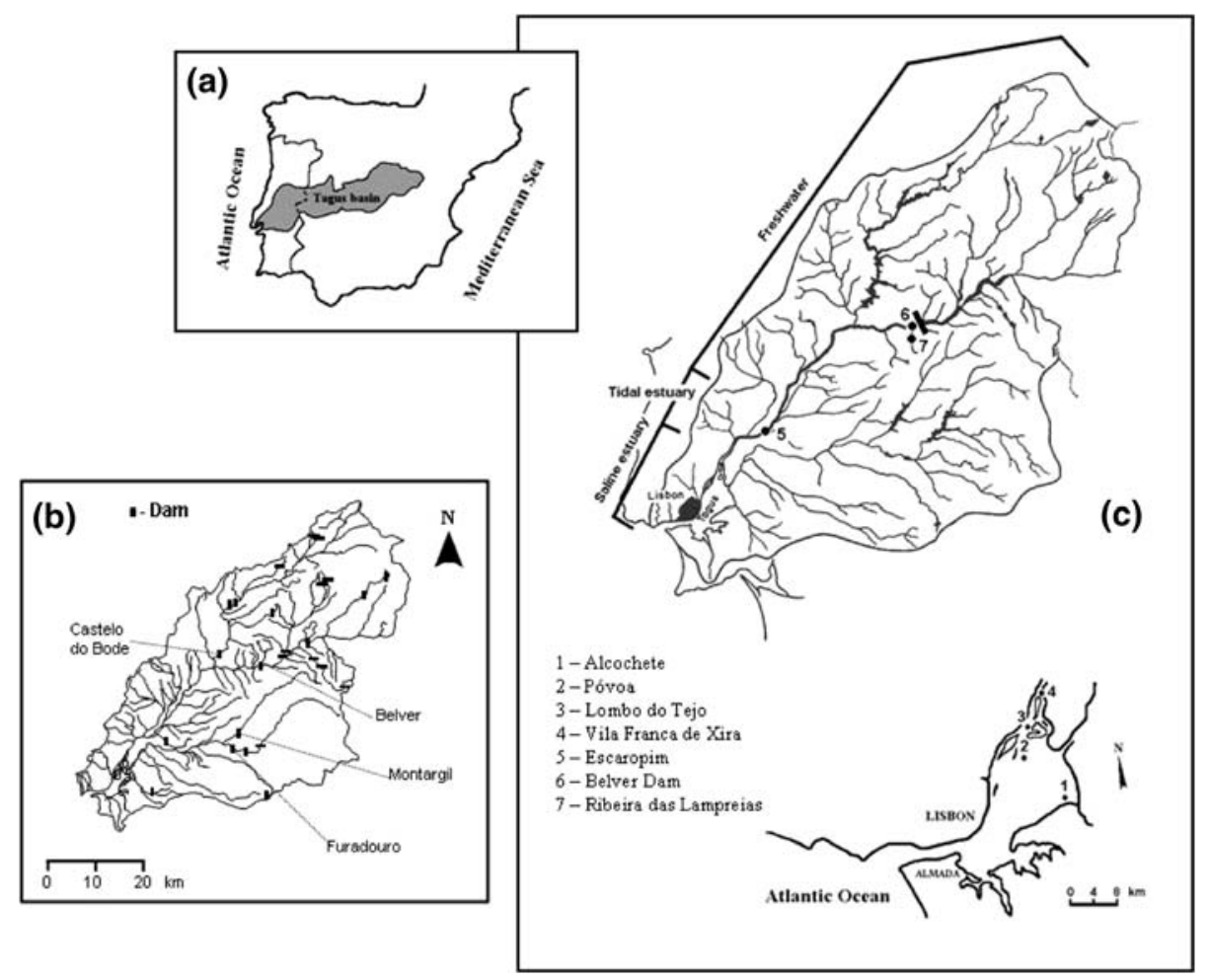

Fig. 1 Tagus river basin (a), respective area currently available to the European eel (b), and location of the sampling sites (c)

river beds and margins and the construction of several dams and weirs are other important anthropogenic constraints in this catchment (Almeida 2002). The estuary is completely surrounded by Lisbon and its suburbs, which produce an enormous amount of domestic sewage (Costa 1999). The Tagus estuary is also subjected to some degree of industrial pressure and to important harbor and fishing activities (Bettencourt et al. 2003).

Historically, the natural population of the European eel colonized the entire Tagus river basin, reaching its Spanish portion, but it is now limited to the lower $158 \mathrm{~km}$. This constraint is due to the presence of the Belver dam (built in 1952) in the main course of the River Tagus (Fig. 1), which is an almost impassable barrier because its fish passage is ineffective (Alexandrino 1990) and, as stated before by Assis (1990), it continues to be frequently inoperative. A similar situation occurs in the two main tributaries that join the River Tagus below the Belver dam, with the River Zêzere interrupted by the Castelo do Bode dam (built in 1951) and the River Sorraia obstructed by the Montargil and Furadouro dams (both built in 1958), all located in their lower reaches (Almeida 2002). Therefore, in the Tagus river basin the European eel is now restricted to about $1,250 \mathrm{~km}$ of streams and rivers, which correspond to an area close to one-half of the original available habitat for the species in the Portuguese part of the catchment (Costa et al. 2001). The situation is aggravated because the number of individuals is small near the river mouth (Costa 1980; Martins et al. 1994). Despite the high variability in density between years, the catches in some estuarine areas showed a clear decrease in the Tagus eel population from 1979-1981 to 1995-1997 periods (Cabral et al. 2001), confirming the decline throughout its distribution area.

\section{Sampling}

A total of seven sampling sites were considered in this study; four in brackish water and three in freshwater (Fig. 1). Except for Ribeira das 
Lampreias they are all situated in the main course of the River Tagus. The six sampling stations located in the main river were chosen to provide information about eel ecology and its population structure along the section of the basin where the species is present in important numbers. Ribeira das Lampreias, a small tributary (about $5 \mathrm{~m}$ wide at the mouth) that joins this river only $500 \mathrm{~m}$ below the Belver dam, was considered in this work for comparison with the adjacent Belver Dam sampling station. The most relevant characteristics of the sampling sites (dominant substrate, degree of cover provided by aquatic vegetation, depth, and salinity) were determined during the surveys and are summarized in Table 1.

Eel captures were performed monthly, during the day, from January 1988 to December 1988. Samples were collected with a beam trawl (10 mm mesh-size) in brackish water and a DC electrofishing equipment $(600 \mathrm{~V}-10 \mathrm{~A})$ in freshwater. The duration of the fishing operations was variable both in time and space, but the time spent in each run was always recorded which allowed for a standardization of the captures.

\section{Laboratory procedures}

After sampling, the eels were taken to the laboratory where they were frozen for further analysis. Once thawed, their total length ( $\mathrm{mm})$ and total weight $(\mathrm{g})$ were measured. The digestive tract of the specimens was removed and the respective stomach contents weighed $(0.001 \mathrm{~g})$ for trophic studies. Since the great majority of the individuals initiate sexual differentiation after reaching the length of $240 \mathrm{~mm}$ (Colombo et al. 1984) the gonads of the eels which were equal to or greater than $240 \mathrm{~mm}$ were examined under a binocular microscope for sex determination using the methodology described by Fernández-Delgado et al. (1989).

\section{Data analysis}

The number of specimens caught in each fishing operation was expressed as the number of eels captured per minute of survey. The mean and median abundance in each sampling site were determined considering data from the 12 collections performed during the year. These operations were conducted for small eels $(<240 \mathrm{~mm})$ and large eels $(\geq 240 \mathrm{~mm})$ separately, as well as combined to determine if the two subsets show the same spatial pattern of abundance. The abundance of the European eel in the different locations was compared by means of Friedman tests using each monthly collection as a replicate, and the identification of homogeneous sets of sites regarding this parameter was performed by the respective post hoc simultaneous test procedure (Siegel and Castellan Jr 1988).

The total length of the individuals captured during the year was used to analyze the size structure of the eel population at each sampling site. The Kruskal-Wallis test and the respective post hoc simultaneous test procedure (Siegel and Castellan Jr 1988) were applied to compare spatial length distributions.

The replicated $G$-test of goodness of fit (Sokal and Rohlf 1995) was used to investigate if the proportion of sexes was different from the 1:1

Table 1 Main characteristics of the sampling sites

\begin{tabular}{|c|c|c|c|c|c|c|}
\hline Sampling sites & $\begin{array}{l}\text { Distance from the sea } \\
(\mathrm{km})\end{array}$ & Location & Bottom type & $\begin{array}{l}\text { Cover by } \\
\text { vegetation }\end{array}$ & $\begin{array}{l}\text { Depth } \\
(\mathrm{m})\end{array}$ & $\begin{array}{l}\text { Mean } \\
\text { salinity }\end{array}$ \\
\hline Alcochete & 29 & Middle estuary & Mud & Low & $1.0-3.0$ & $20-25$ \\
\hline Póvoa & 32 & Middle estuary & Mud + Sand & Low & $2.0-5.0$ & $10-15$ \\
\hline Lombo do Tejo & 36 & Upper estuary & Mud + Sand & Low & $2.0-7.0$ & $<10$ \\
\hline $\begin{array}{l}\text { Vila Franca de } \\
\text { Xira }\end{array}$ & 43 & Upper estuary & Mud + Sand & Low & $2.0-6.0$ & $<5$ \\
\hline Escaropim & 65 & Freshwater tidal area & Sand & Low & $0.5-1.5$ & 0 \\
\hline Belver Dam & 158 & $\begin{array}{l}\text { Freshwater (main } \\
\text { course) }\end{array}$ & Gravel + Rock & Medium & $0.5-2.0$ & 0 \\
\hline $\begin{array}{l}\text { Ribeira das } \\
\text { Lampreias }\end{array}$ & 158 & $\begin{array}{l}\text { Freshwater (small } \\
\text { tributary) }\end{array}$ & Gravel & High & $0.5-1.0$ & 0 \\
\hline
\end{tabular}


expected ratio (considering all individuals captured along the year) both for the entire sample and for each location separately, and if there was heterogeneity between the sites regarding the sex ratio. Whenever possible, these tests were conducted using the more conservative Williams' correction.

The individual condition coefficients (CC) were estimated using the following expression adapted from Bagenal and Tesch (1978):

$\mathrm{CC}=\frac{\boldsymbol{T} \boldsymbol{W}}{\boldsymbol{T} \boldsymbol{L}^{3}} \times 10^{c}$,

where $T W$ and $T L$ are the total weight and the total length of each indvidual, respectively, and $c$ is equal to 5 , since in this case the weight is expressed in grams and the length in millimetres.

To define the degree of feeding intensity of the individuals their stomach fullness index (FI) was computed according to Hyslop (1980):

$\mathrm{FI}=\frac{\boldsymbol{S} \boldsymbol{C W}}{\boldsymbol{T} \boldsymbol{W}} \times 100$,

where $S C W$ and $T W$ are the stomach content weight and the total weight of each animal, respectively.

Both the CCs and the stomach FIs were spatially compared using the Kruskal-Wallis test and the respective post hoc simultaneous test procedure applied to all specimens captured during the year. The relationship between the condition of the individuals and their stomach fullness was investigated by means of the Spearman correlation coefficient considering each location as an object (Siegel and Castellan Jr 1988). All these operations were performed for small eels $(<240 \mathrm{~mm})$ and large eels $(\geq 240 \mathrm{~mm})$ separately, as well as combined to detect ontogenetic variations in these parameters.

Due to potential differences in the selectivity of the fishing gears used in brackish water (beam trawl) and freshwater (electrofishing), the comparative analyses of abundance and size structure in the different areas were performed separately for both ecosystems. Only specimens collected in the early morning were considered for the analyses of feeding intensity because of this species' preference to feed during the night period (Tesch 1977).

The replicated $G$-test of goodness of fit was conducted using the BIOMstat software, whereas all the other tests were performed using the SPSS statistical package. The level of significance used in all analyses was 0.05 .

\section{Results}

Characteristics of the sample

A total of 1,816 eels ranging from 63 to $706 \mathrm{~mm}$ in total length were captured in the Tagus river basin during the study period. Almost $75 \%$ of the specimens analyzed were smaller than $240 \mathrm{~mm}$ and from the remaining $25 \%$ of the individuals, more than $75 \%$ were sexually differentiated.

\section{Abundance}

When considering all sizes together (Table 2), in brackish water the species was more abundant in the middle estuary, especially at Alcochete, and less common upstream (Vila Franca de Xira). In freshwater the highest captures were obtained at Ribeira das Lampreias and the lowest at Escaropim. The same spatial patterns of abundance were obtained when considering small eels and large eels separately and therefore these results will not be presented.

\section{Size structure}

The reduced proportion of eels smaller than $180 \mathrm{~mm}$ caught by the beam trawl, when compared with the pattern obtained for the electrofishing operations, seems to confirm the existence of considerably different size selectivity between the two fishing methods (Fig. 2). Furthermore, the electrofishing apparatus enabled the capture of eels smaller than $100 \mathrm{~mm}$ at Escaropim, a size class that is missing in all other estuarine sampling stations.

There were marked differences in the length of the specimens among sites in both brackish water and freshwater (Fig. 2). In brackish water the size 
Table 2 Eel abundance (all sizes together) in the different sampling sites and results of the Friedman tests performed to independently compare those values for brackish water and freshwater

\begin{tabular}{|c|c|c|c|c|c|c|}
\hline \multirow[t]{2}{*}{ Sampling sites } & & \multirow{2}{*}{$\begin{array}{l}\text { Number } \\
\text { of eels } \\
\text { caught }\end{array}$} & \multicolumn{3}{|c|}{ Abundance (eels $\min ^{-1}$ ) } & \multirow[t]{2}{*}{ Test results } \\
\hline & & & Mean & Median & Interquartile range & \\
\hline \multirow[t]{4}{*}{ Brackish water } & Alcochete (AL) & 235 & 63.8 & 58.7 & $33.3-87.7$ & $\begin{array}{l}\chi^{2}=7.92, d f=3, p<0.05 \\
\text { VF PV LT AL }\end{array}$ \\
\hline & Póvoa (PV) & 121 & 67.2 & 36.7 & $13.3-60.0$ & $\overline{\overline{ }} \overline{ }$ \\
\hline & Lombo do Tejo (LT) & 280 & 57.2 & 34.4 & $15.0-93.3$ & \\
\hline & Vila Franca de Xira (VF) & 105 & 29.2 & 8.3 & $0.0-22.5$ & \\
\hline \multirow[t]{3}{*}{ Freshwater } & Escaropim (ES) & 153 & 49.2 & 25.3 & $12.1-66.7$ & $\begin{array}{c}\chi^{2}=8.98, d f=2, p<0.05 \\
\text { ES BD RL }\end{array}$ \\
\hline & Belver Dam (BD) & 268 & 91.9 & 45.7 & $15.4-162.5$ & \\
\hline & Ribeira das Lampreias (RL) & 654 & 120.2 & 96.7 & $65.8-152.1$ & \\
\hline
\end{tabular}

Rules group the non-significant subsets

of the eels was larger at the middle estuarine area (Póvoa), mainly because the proportion of small individuals $(<220 \mathrm{~mm})$ was reduced. The preponderance of small eels increased to the periphery of the estuary with a clear dominance of smaller individuals near the limnetic zone (Vila Franca de Xira). In freshwater the length of the eels increased upstream with a higher predominance of larger eels below the Belver dam.

\section{Sexual structure}

The proportion of males was higher than the proportion of females with a global sex ratio of $3: 2$ (Table 3). Nevertheless, there was a strong heterogeneity among the different locations with a significant dominance of males only at Alcochete (ratio of 3:1), Belver Dam (ratio of 3:2) and Ribeira das Lampreias (ratio of 6:1) sampling stations.

\section{Body condition}

Two preliminary tests revealed significant differences among the CCs of the eels captured for both brackish water $\left(\chi^{2}=42.38, \quad d f=3\right.$, $p<0.001)$ and freshwater $\left(\chi^{2}=31.32, d f=2\right.$, $p<0.001)$. Therefore, additional analyses were performed for each environment considering all sites separately.

When considering all eels, as well as the eels with less than $240 \mathrm{~mm}$, the brackish water specimens attained a globally better condition than those collected upstream, showing the animals below the Belver dam to be in the worst condition of all (Fig. 3). The pattern observed for large eels $(\geq 240 \mathrm{~mm})$ was quite different from the one described before, with the lowest condition of individuals at Alcochete, Ribeira das Lampreias, and Belver Dam, precisely the sites where the highest abundances were recorded. The maximum value for the large eels' CC was observed at Escaropim.

\section{Feeding intensity}

The stomach FI showed no significant differences among sites in the brackish water environment $\left(\chi^{2}=0.16, d f=3\right.$, NS $)$, in contrast with freshwater $\left(\chi^{2}=13.42, d f=2, p<0.01\right)$. Thus, in the subsequent analyses all the eels caught in brackish water were grouped together but those captured in freshwater were kept separate according to their original location.

Independent of the size of the eels those from brackish water consistently showed the highest feeding intensity while those from the Belver Dam station attained the lowest values (Fig. 4). The main variation in feeding activity between the small individuals $(<240 \mathrm{~mm})$ and the larger ones $(\geq 240 \mathrm{~mm})$ occurred at Ribeira das Lampreias where the stomach FI reveals a clear decrease in larger specimens. 

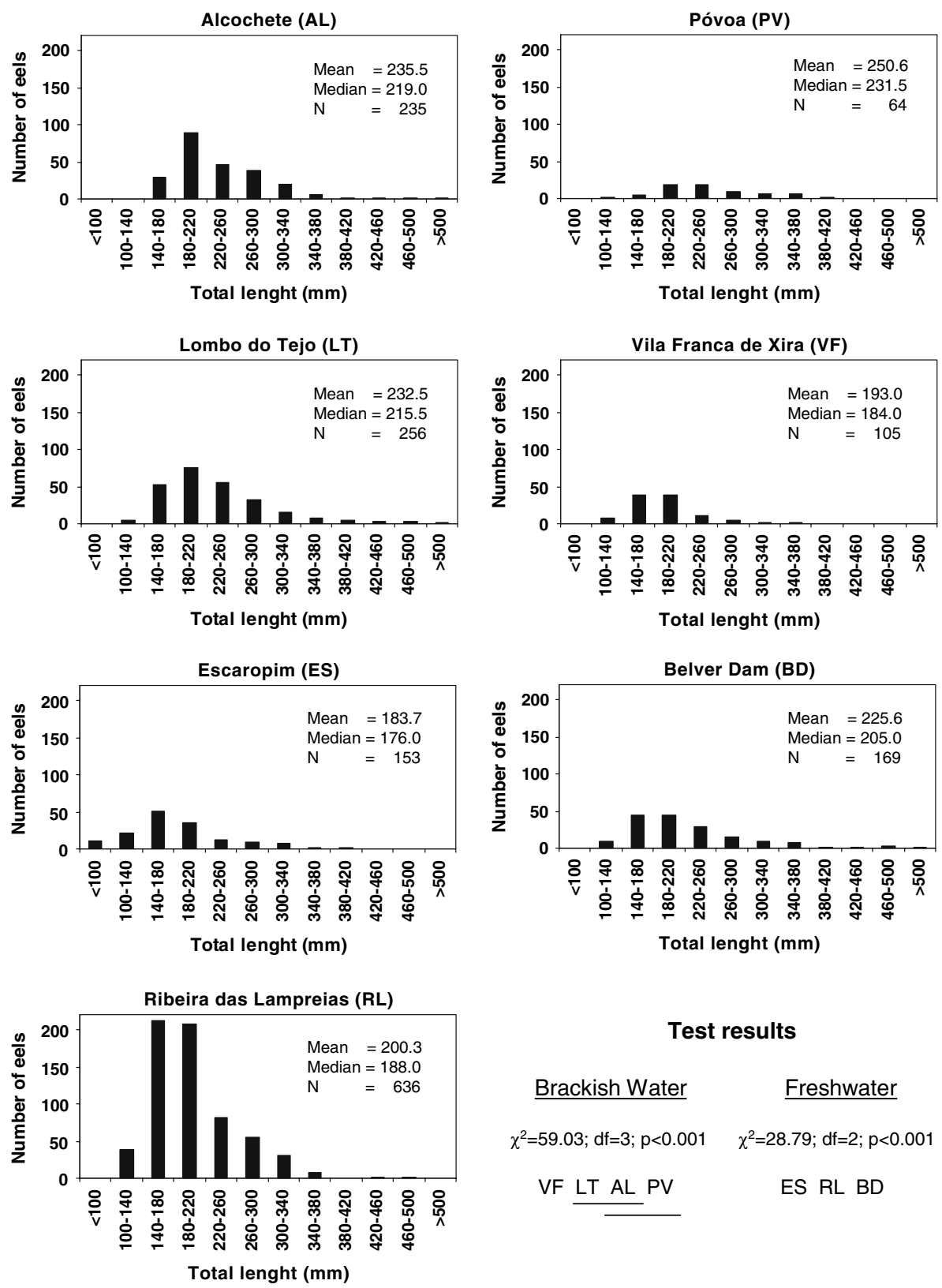

Fig. 2 Comparison of the eel population size structure in the different sampling sites, including the results of the KruskalWallis tests performed separately for brackish water and freshwater (rules join the non-significant subsets)

Body condition and feeding intensity interrelation

The CC and the stomach FI showed a direct association for the whole set of specimens $\left(r_{\mathrm{s}}=0.83, N=7, p<0.05\right)$ and for small individuals $\left(r_{\mathrm{s}}=0.80, N=7, p<0.05\right)$ but not for the larger individuals $\left(r_{\mathrm{s}}=0.47, N=7, \mathrm{NS}\right)$. The lack of a significant correlation between both parameters for larger eels was greatly influenced by the sample from Escaropim where the specimens presented a relatively low-feeding intensity but a high-body condition. 
Table 3 Proportion of male and female eels in the sampling sites and results of the $G$-test of goodness of fit

\begin{tabular}{lllll}
\hline Sampling sites & Percentage of males & Percentage of females & Sample size & Test results \\
\hline Alcochete & 75.6 & 24.4 & 82 & $G_{\mathrm{W}}=22.43, d f=1, p<0.001$ \\
Póvoa & 32.0 & 68.0 & 25 & $G_{\mathrm{W}}=3.25, d f=1, \mathrm{NS}$ \\
Lombo do Tejo & 40.7 & 59.3 & 86 & $G_{\mathrm{W}}=2.22, d f=1, \mathrm{NS}$ \\
Vila Franca de Xira & 66.7 & 33.3 & 12 & $G_{\mathrm{W}}=1.90, d f=1, \mathrm{NS}$ \\
Escaropim & 63.6 & 36.4 & 22 & $G_{\mathrm{W}}=1.62, d f=1, \mathrm{NS}$ \\
Belver Dam & 65.2 & 13.8 & 46 & $G_{\mathrm{W}}=4.28, d f=1, p<0.05$ \\
Ribeira das Lampreias & 86.2 & - & 29 & $\mathrm{G}_{\mathrm{W}}=16.64, d f=1, p<0.001$ \\
Heterogeneity between sites & - & 39.7 & 302 & $G=39.05, d f=1, p<0.001$ \\
Total of the sites & 60.3 & & $G=53.01, d f=1, p<0.001$ \\
\hline
\end{tabular}

$G-G$-statistic; $G_{\mathrm{W}}-G$-statistic with the Williams' correction

\section{Discussion}

Although invasion mechanisms of continental systems by anguillids are poorly documented (Ibbotson et al. 2002; Feunteun et al. 2003) it is generally accepted that the distance from the sea is the driving force structuring density, average size, age, and sex ratio of eels (e.g., Naismith and Knights 1993; Laffaille et al. 2003). Nevertheless, other factors such as the presence of obstacles to upstream migration, depth, cover, and biotic interactions seem to play an equally important role, especially at smaller spatial scales (e.g., Jellyman et al. 2003; Laffaille et al. 2003; Domingos et al. 2006).

After arrival in brackish water, young eels show great variability in the extension of their upstream migration (Moriarty 1987). The common pattern is that large amounts of individuals remain in estuaries (the foundators) and density gradually decreases upriver, since the influx of (the pioneer) eels declines with distance from the estuary (e.g., Sloane 1984; Naismith and Knights 1993; Tzeng et al. 1995; Feunteun et al. 2003). Eel density also decreases near the sea, as only a small proportion of the glass eels reaching coastal waters remains in that region (Tesch 1977). Nevertheless, small river systems and the presence of barriers to migration may disrupt this pattern (Laffaille et al. 2003; Morrison and Secor 2004).

The abundance values estimated for the European eel in the Tagus estuary are in agreement with the common pattern observed for other anguillid populations: higher number of individuals in the middle estuary and an upstream decrease in density. The species is also rare near the river mouth (Costa 1980; Martins et al. 1994) and apparently absent from the adjacent marine area (Cabral et al. 2000; Prista et al. 2003). According to Moriarty (1987) eel scarcity in the lower reaches of the river basins and in the adjoining seas is related to the avoidance of predators and competitors for space and food resources, which are usually abundant in more saline areas but decrease sharply upstream, as reported by Cabral (1998) for the Tagus estuary.

Although the differential selectivity of the two fishing methods used did not allow a direct comparison between the abundance estimates for brackish water and freshwater, the field observations indicated that there is a general decrease in the species abundance from the upper saline estuary (Vila Franca de Xira) to the freshwater tidal area (Escaropim). According to the described patterns of distribution, a low abundance would be expected in the upstream sampling sites. However, Escaropim yielded poor catches when compared with the Belver Dam and especially with Ribeira das Lampreias sampling sites. In a previous study Costa et al. (1992a) estimated a density of 895 eels per $1,000 \mathrm{~m}^{2}$ in this tributary. In spite of its greater distance from the river mouth, Ribeira das Lampreias yielded much higher densities than other European rivers (Table 4). Only some sites near the sea (less than $30 \mathrm{~km}$ upstream) showed densities of the same magnitude (Legault 1986; Feunteun et al. 1998, 2000; Ibbotson et al. 2002; Laffaille et al. 2003).

Despite being present in the Belver reservoir (Ferreira and Godinho 2002), eels are seldom 

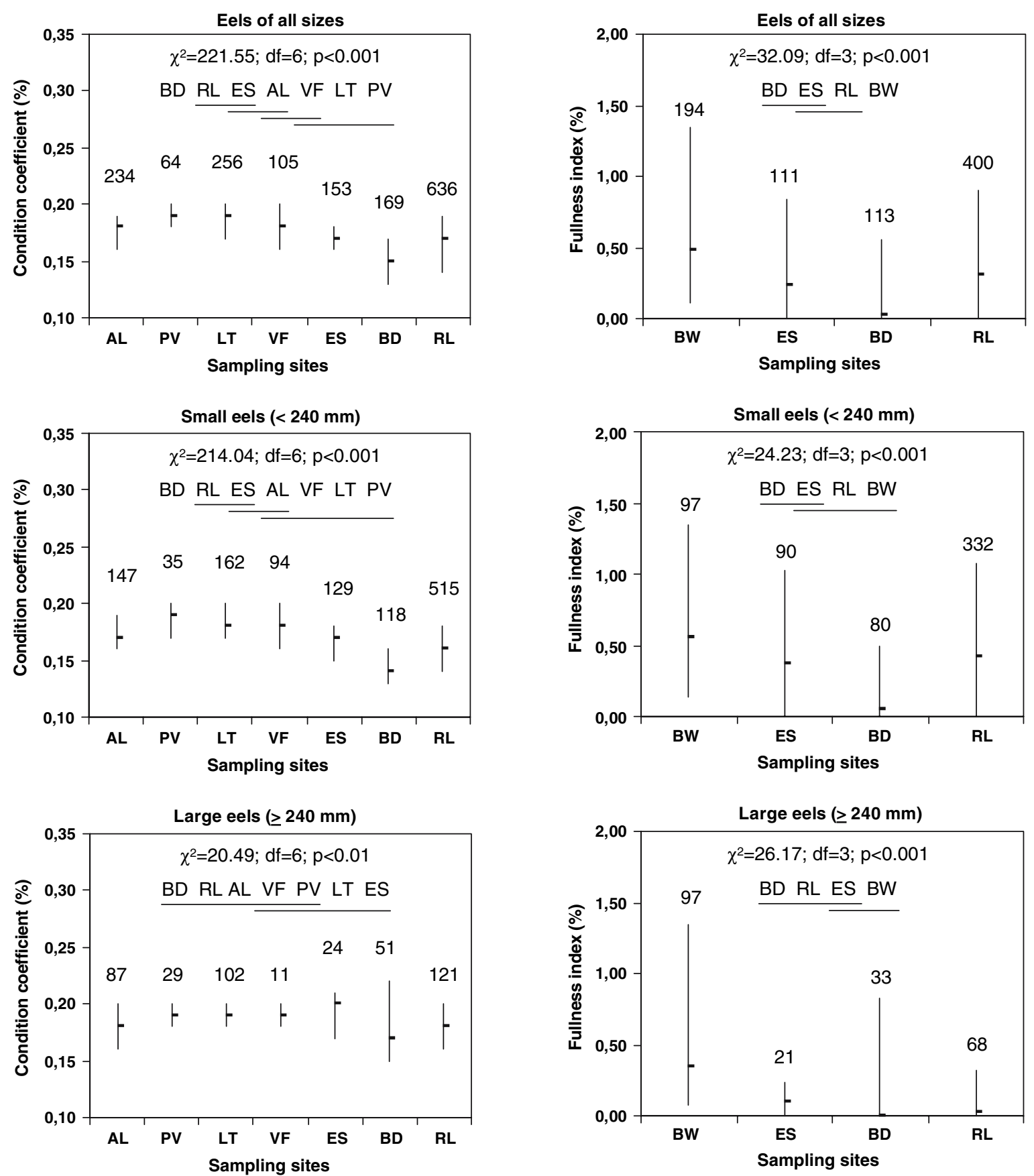

Fig. 3 Comparison of the condition coefficient of the eels captured in the different sampling sites ( $A L$ Alcochete, $P V$ Póvoa, $L T$ Lombo do Tejo, $V F$ Vila Franca de Xira, ES Escaropim, $B D$ Belver Dam, $R L$ Ribeira das Lampreias), including the results of the Kruskal-Wallis tests performed for the different length classes (rules join the nonsignificant subsets) and the size of the samples (over quartile bars)

Fig. 4 Comparison of the stomach fullness index of the eels captured in the different sampling sites ( $B W$ All brackish water stations, ES Escaropim, $B D$ Belver Dam, $R L$ Ribeira das Lampreias), including the results of the Kruskal-Wallis tests performed for the different length classes (rules join the non-significant subsets) and the size of the samples (over quartile bars) 
Table 4 Eel densities in several European rivers

\begin{tabular}{llccl}
\hline Country & River & $\begin{array}{l}\text { Distance form the river } \\
\text { mouth }(\mathrm{km})\end{array}$ & Density (eels $\left.\times 1,000 \mathrm{~m}^{-2}\right)$ & References \\
\hline Norway & Imsa & - & 12 & Vøllestad and Jonsson (1988) \\
Denmark & Lellinge & 25 & 595 & Rasmussen and Therkildsen (1979) \\
France & Longève & 35 & 350 & Legault (1986) \\
France & Autize & 41 & 148 & Legault (1986) \\
France & Autize & 95 & 37 & Legault (1986) \\
France & Chambon & 101 & 31 & Legault (1986) \\
France & Chambon & 119 & 12 & Legault (1986) \\
Portugal & Ribeira das & 158 & 895 & Costa et al. (1992a) \\
& Lampreias & & & \\
\hline
\end{tabular}

caught by fishermen above the dam. Hence, the presence of this barrier clearly inhibits upstream migration, promoting a forced concentration of specimens below the dam and leading to unexpected high densities at sites so distant from the sea. Such concentration of eels downstream of obstacles to migration has been described for coastal river systems, namely the Rhone catchment or the River Frémur in France (Feunteun et al. 1998). Considering that the mortality in freshwater is regulated by density-dependent factors (Vøllestad and Jonsson 1988) and that freshwater yellow eels show a sedentary behavior (Feunteun et al. 2003), this situation may exert detrimental effects on the population.

It has been suggested that in anguillid eels sex determination is density-dependent, with greater densities leading to a higher proportion of males (Sinha and Jones 1966; Tesch 1977; Vøllestad and Jonsson 1988). Thus, the sexual structure of the European eel in the Tagus is also in agreement with what was expected, with a significant dominance of males where the species exhibits the greatest abundance both in brackish water (Alcochete) and in freshwater (Belver Dam and Ribeira das Lampreias). Therefore, the forced concentration of eels below the Belver dam may result in the artificial manipulation of the sex ratio leading to a decrease in the expected proportion of females for this area, and contributing to a general dominance of males (global sex ratio of 3:2).

Despite the general positive correlation between the condition of eels and their stomach fullness in the Tagus, two exceptions occurred. At Escaropim, large eels $(\geq 240 \mathrm{~mm})$ fed less intensively but showed a better condition than eels from brackish water, whereas in Alcochete both size classes presented a poorer condition than in the other brackish water sites but exhibited the same level of feeding activity. Therefore, the lower condition of eels from Alcochete cannot be attributed to a decrease in food intake related to their higher abundance, since the stomach FI does not reflect any decrease in feeding intensity. However, higher abundances promote a more competitive environment where the search for food, the number of confrontations among individuals and the increase of physiological constraints certainly have additional energetic costs (Vøllestad and Jonsson 1988; Costa 2004), which are probably implicated in the impoverished condition of the individuals. Similarly, the reduced abundance at Escaropim may have contributed to the better condition of eels in that area despite their apparent lower feeding intensity. Nevertheless, that pattern is only detectable for larger eels, precisely those whose abundance proportionally increases upstream. Therefore, the observed variations in condition may result from the additional energetic losses related to the maintenance of the osmotic balance in the brackish water environment (Tesch 1977), which are usually more detrimental for larger specimens (Davenport and Sayer 1993). Naturally, other differences related to habitat features, which have not been addressed in the present study, could have also contributed to the spatial variations detected in the specimens' condition.

The decrease in the eels' feeding intensity from the estuarine sampling sites to the Belver dam 
region is probably related to the natural reduction in prey availability which is reported as decreasing from the lower areas to the upper reaches of the catchments (Maitland 1978). This decline may have contributed to the poor condition of the specimens caught below the Belver dam and at Ribeira das Lampreias. The presence of the dam may have increased this trend not only as a consequence of the higher densities but also because there is usually a decline in biological richness and consequently in the prey availability in the areas immediately below the dams (Maitland 1978). Additionally, in the southern region of this species geographical range, the highsummer temperatures, which occur in freshwater reduce the activity of eels, similar to the reduction in activity that occurs in the winter months (J. L. Costa, unpublished data). These are probably the reasons why estuarine eels, in this warmer region, exhibit a better condition than other brackish water populations of the European eel (GandolfiHornyold 1930, 1935; Tesch 1977; Rossi and Villani 1980), whereas the opposite occurs when comparing the stations immediately below the Belver dam with other freshwater populations (Sinha and Jones 1967; Tesch 1977; Neveu 1981).

Some authors suggest that small fish preferably occupy shallow peripheral habitats, with abundant cover, whereas larger fish occur in more exposed and deeper central zones (e.g., Wiederholm 1987; Domingos 2003; Laffaille et al. 2003; Costa 2004). According to these authors the mechanisms responsible for this segregation seem to be related to physiological constraints as well as to competition, predation risk and food availability. On the other hand, it is commonly accepted that eel length increases with distance from the sea (e.g., Legault 1986; Tzeng et al. 1995; Ibbotson et al. 2002; Domingos 2003; Laffaille et al. 2003). Data from the freshwater zone of the Tagus river basin indicate that such a trend is generally observed in this catchment and due to the duration of the migration and the growth of the individuals during their upstream migration the presence of very small eels is rare in the upper reaches of the basin. However, the results from the brackish water sampling sites contradict that pattern. In the Tagus estuary, dominant larger eels prevail in the central area of distribution
(Póvoa), while smaller individuals are pushed to peripheral zones either upstream (Lombo do Tejo and Vila Franca de Xira) or to the margins (Alcochete). This mechanism reduces the potential competition and the risk of predation on small specimens, not only due to the spatial segregation among size classes but also because those marginal areas are less available to other fish species and especially to predators (Cabral 1998; Costa 1999). It also confirms several patterns of distribution described in a range of river systems (Feunteun et al. 2003).

Given the described strategy, a significant part of the young eel population is pushed further up into freshwater, where the importance of tributaries becomes evident, especially for small eels $(<240 \mathrm{~mm})$. In fact, considering the Belver Dam and the Ribeira das Lampreias sites, where density was high, small eels probably found better trophic conditions in the small stream than in the adjacent main river located at the same distance from the sea and exhibited a feeding intensity similar to the eels from Escaropim. On the contrary, Ribeira das Lampreias seemed to be less favorable to larger eels $(\geq 240 \mathrm{~mm})$ since the values of feeding intensity of this size group in this stream were similar to those obtained at the Belver Dam site. The observed differences in feeding intensity seem to be reflected in the condition of the individuals and are probably responsible for a higher proportion of small eels at Ribeira das Lampreias when compared with the adjoining main river. Nevertheless, due to the presumably better trophic conditions of Ribeira das Lampreias, even the larger specimens exhibit a slightly higher abundance on that tributary than in the adjacent River Tagus area.

\section{Conclusion}

As in most anguillid populations, the eels from the Tagus river basin are more abundant in the middle estuary and decrease in both upstream and downstream directions with males dominating in high-density areas. The dominance of larger specimens, the need to avoid predators and the search for better trophic conditions seem to push smaller individuals to more peripheral areas, such 
as the margins and the upper estuary in brackish water, and the tributaries in the freshwater zone. Because of an apparent natural decrease in the feeding intensity toward the upper reaches of the catchment, the condition of the individuals generally follows the same pattern although some minor variations, probably related to the population density and the maintenance of the osmotic balance, were detected.

The presence of the almost impassable Belver dam located $158 \mathrm{~km}$ upstream from the river mouth imposes major changes to the patterns described for the lower River Tagus and for most water basins. The forced concentration of eels below the obstacle may have consequences on the breeding success of this population due to the artificial manipulation of the sex ratio, and to the decrease in the number and condition of individuals, which certainly contribute to a decline in the potential spawning biomass. This situation can be expanded to the two major Tagus tributaries below the Belver dam (rivers Zêzere and Sorraia) where a small number of eels are found upstream of the first obstacles located in their lower reaches.

Since most of the consequences of dams are related to density, the recent overall decline in the abundance of the European eel may have induced important changes to the situation observed in the Tagus river basin 15 years ago. Therefore, to get an updated overview of the impacts of the major dams on this population it is important to conduct new sampling campaigns not only in the main course of the River Tagus but also in its main tributaries below the Belver dam. However, since no alterations were introduced in the functioning of the Belver dam fish passage over the past 15 years, this structure is still responsible for a considerable reduction of the available habitat for eels and other diadromous fishes. Thus, this obstacle will continue to be a serious constraint unless a specific eel passage is installed in the dam or alternatively, some modifications are made both in structure and functioning of the existing fish passage. In terms of structure, the fish passage should be analyzed and altered to improve its efficiency for the eels. As for the functioning regime, the fish passage should start to operate more intensively, especially at night, at least from November to March, when glass and silver eel migrations are more intense. In that case, it will also be necessary to examine downstream passage through the Belver dam to enable escapement of silver eels and to improve spawning biomass production of the Tagus river basin.

Acknowledgments The field work was undertaken with the financial support of the project "Structure and functioning of the animal communities of the Tagus estuary; their relationships with the anthropogenic alterations" funded by Fundação para a Ciência e a Tecnologia (FCT). This study was also supported by two grants (BJI/M 43/87 and SFRH/BPD/18403/2004) from FCT.

\section{References}

Alexandrino P (1990) Primeiros dados sobre a eficácia da eclusa de Borland da barragem de Belver, rio Tejo. Alguns aspectos sobre a biologia das espécies migradoras. In: Santana F, Santos MC, Costa MH, Pereira D (eds) II Conferência nacional sobre a qualidade do ambiente, vol 2. Universidade Nova de Lisboa, Lisbon, $\mathrm{p} 1$

Almeida PR (2002) Ictiofauna fluvial. In: Moreira I, Ferreira MT, Cortes R, Pinto P, Almeida PR (eds) Ecossistemas aquáticos e ribeirinhos. Ecologia, gestão e conservação. Instituto da Água, Lisbon, p 7.1

Antunes C (1994) Estudo da migração e metamorfose de Anguilla anguilla L. por análise dos incrementos dos sagittae, em leptocéfalos e enguias de vidro. Dissertation, Universidade do Porto

Assis CA (1990) Threats to the survival of anadromous fishes in the River Tagus, Portugal. J Fish Biol 27(Suppl A):225-226

Bagenal TB, Tesch F-W (1978) Age and growth. In: Bagenal TB (ed) Methods for assessment of fish production in fresh waters, $3 r d$ edn. Blackwell, London, p 101

Bessa R, Castro M (1994) Evolução das capturas de meixão ao longo do ano no rio Lis e sua relação com as condições ambientais. Relat Técn Cient IPIMAR 2:1-18

Bettencourt AM, Gomes FV, Dias JA, Ferreira JG, Silva MC, Costa JL (2003) Estuários portugueses. Instituto da Água, Lisbon

Cabral H (1998) Utilização do estuário do Tejo como área de viveiro pelos linguados, Solea solea (L., 1758) e Solea senegalensis Kaup, 1858, e robalo, Dicentrarchus labrax (L., 1758). Dissertation, Universidade de Lisboa

Cabral H, Costa MJ, Salgado JP (2001) Does the Tagus estuary fish community reflect environmental changes? Clim Res 18:119-126

Cabral H, Duque J, Costa MJ (2000) Importance of the costal zone adjacent to the Tagus estuary as a nursery area for fish. Thalassas 16:27-32 
Colombo G, Grandi G, Rossi R (1984) Gonad differentiation and body growth in Anguilla anguilla. J Fish Biol 24:215228

Costa JL (2004) A biologia do xarroco Halobatrachus didactylus (Bloch \& Schneider, 1801) e o seu papel na estrutura e funcionamento dos ecossistemas em que se insere; referência especial à população do estuário do Mira. Dissertation, Universidade de Lisboa

Costa JL, Almeida PR, Assis CA, Moreira F, Costa MJ (1992a) A study of methods of estimating the size of eel populations in small streams. Ir Fish Invest (Ser A) 36:68-69

Costa JL, Assis CA, Almeida PR, Moreira F, Costa MJ (1992b) On the food of the European eel, Anguilla anguilla (L.), in the upper zone of the Tagus estuary, Portugal. J Fish Biol 41:841-850

Costa MJ (1980) Fishes of Tejo estuary. Arq Mus Boc (2nd Ser) 7:291-316

Costa MJ (1999) O estuário do Tejo. Cotovia, Lisbon

Costa MJ, Almeida PR, Costa JL, Assis CA, Moreira F (1993) Algumas notas sobre a capacidade adaptativa da enguia Europeia, Anguilla anguilla (L., 1758), e das tainhas (Fam. Mugilidae): referência especial às populações do Tejo. Publ Inst Zool Dr Augusto Nobre 233:1-17

Costa MJ, Almeida PR, Domingos I, Costa JL, Correia MJ, Chaves ML, Teixeira CM (2001) Present status of the main shads' populations in Portugal. Rev Trav Inst Pêches Mar 362/363:1109-1116

Davenport J, Sayer MD (1993) Physiological determinants of distribution in fish. J Fish Biol 43(Suppl A):121-145

Dekker W (2003) Did lack of spawners cause the collapse of the European eel, Anguilla anguilla? Fish Manag Ecol 10:365-376

Domingos I (1992) Fluctuation of glass eel migration in the Mondego estuary (Portugal) in 1988 and 1989. Ir Fish Invest (Ser A) 36:1-4

Domingos I (2002) Glass eel migration and fisheries in the Mondego estuary-future perspectives. In: Pardal MA, Marques JC, Graça MA (eds) Aquatic ecology of the Mondego river basin. Global importance of local experience. Imprensa da Universidade de Coimbra, Coimbra, p 493

Domingos I (2003) A enguia europeia, Anguilla anguilla (L. 1758), na bacia hidrográfica do rio Mondego. Dissertation, Universidade de Lisboa

Domingos I, Costa JL, Costa MJ (2006) Factors determining length distribution and abundance of the European eel, Anguilla anguilla, in the River Mondego (Portugal). Freshw Biol 51:2265-2281

Fernández-Delgado C, Hernando J, Herrera M, Bellido M (1989) Age and growth of yellow eels, Anguilla anguilla, in the estuary of the Guadalquivir River (South-West Spain). J Fish Biol 34:561-570

Ferreira MT, Godinho F (2002) Comunidades biológicas de albufeiras. In: Moreira I, Ferreira MT, Cortes R, Pinto P, Almeida PR (eds) Ecossistemas aquáticos e ribeirinhos. Ecologia, gestão e conservação. Instituto da Água, Lisbon, p 10.1

Feunteun E (2002) Management and restoration of European eel population (Anguilla anguilla): an impossible bargain. Ecol Eng 18:575-591
Feunteun E, Acou A, Guillouët J, Laffaille P, Legault A (1998) Spatial distribution of an eel population (Anguilla anguilla L.) in a small coastal catchment of Northern Brittany (France). Consequences of hydraulic works. Bull Fr Pêche Piscic 349:129-139

Feunteun E, Acou A, Laffaille P, Legault A (2000) The European eel (Anguilla anguilla, L.): prediction of spawner escapement from continental population parameters. Can J Fish Aquat Sci 57:1627-1635

Feunteun E, Laffaille P, Robinet T, Briand C, Baisez A, Olivier JM, Acou A (2003) A review of upstream migration and movements in inland waters by anguillid eels: towards a general theory. In: Aida K, Tsukamoto K, Yamauchi K (eds) Eel biology. Springer, Berlin, p 191

Gandolfi-Hornyold AG (1916a) Les anguilles de la Ria de Aveiro. Bull Soc Port Sci Nat 7:172-183

Gandolfi-Hornyold AG (1916b) Observations sur les anguilles du marché de Lisbonne. Bull Soc Port Sci Nat 7:184-197

Gandolfi-Hornyold AG (1918) Quelques observations sur la montée à Lisbonne. Mems Soc Port Sci Nat $3: 1-53$

Gandolfi-Hornyold AG (1930) Le sexe et la croissance de la petite anguille de la Roubine du pont de Rousty (Camargue). Bull Soc Cent Aquic Pêche 37:1-11

Gandolfi-Hornyold AG (1935) Le sexe et la croissance de la petite anguille jaune du marais de la Grand Mar (Camargue). Bull Soc Cent Aquic Pêche 42:73-84

Gordo LS, Jorge IM (1991) Age and growth of the European eel, Anguilla anguilla (Linnaeus, 1758) in the Aveiro Lagoon, Portugal. Sci Mar 55:389-395

Helfman GS, Bozeman EL, Brothers EB (1984) Size, sex and age of American eels in a Georgia River. Trans Am Fish Soc 113:132-141

Hyslop EV (1980) Stomach content analysis-a review of methods and their application. J Fish Biol 17:411-429

Ibbotson A, Smith J, Scarlett P, Aprahamian M (2002) Colonisation of freshwater habitats by the European eel Anguilla anguilla. Freshw Biol 47:1696-1706

Jellyman DJ, Bonnet ML, Sykes JR, Johnstone P (2003) Contrasting use of daytime habitat by two species of freshwater eel Anguilla spp. in New Zealand rivers. Am Fish Soc Symp 33:63-78

Laffaille P, Feunteun E, Baisez A, Robinet T, Acou A, Legault A, Lek S (2003) Spatial organisation of European eel (Anguilla anguilla, L.) in a small catchment. Ecol Freshw Fish 12:254-264

Legault A (1986) Distribution du peuplement d'anguille (Anguilla anguilla L.) à l'échelle d'un bassin versant: étude en Sèvre Niortaise. Vie Milieu 36:261-265

Maitland PS (1978) Biology of freshwaters. Blackie, Glasgow

Martins R, Cascalho A, Franca MLP (1994) Prospecção e avaliação de recursos vivos (peixes, moluscos e crustáceos) de interesse económico no estuário do Tejo. In: Franca MPL, Oliveira MRL, Nunes LP (eds) Seminário sobre recursos haliêuticos, ambiente, aquacultura e qualidade do pescado da Península de Setúbal. Instituto Português de Investigação Marítima, Lisbon, p 17 
Moriarty C (1987) Factors influencing recruitment of the Atlantic species of anguillid eels. Am Fish Soc Symp 1:483-491

Morrison WE, Secor DH (2004) Abundance of yellowphase American eels in the Hudson River estuary. Trans Am Fish Soc 133:896-910

Naismith IA, Knights B (1993) The distribution, density and growth of the European eel, Anguilla anguilla, in the freshwater catchment of the River Thames. J Fish Biol 42:217-226

Neveu A (1981) Variations saisonnières et journalières de l'alimentation de l'anguille (Anguilla anguilla L.), dans des conditions naturelles. Acta Oecol (Oecol Appl) 2:99-116

Prista N, Vasconcelos RP, Costa MJ, Cabral H (2003) The demersal fish assemblage of the coastal area adjacent to the Tagus estuary (Portugal): relationships with environmental conditions. Oceanol Acta 26:525-536

Rasmussen G, Therkildsen B (1979) Food, growth and production of Anguilla anguilla L. in a small Danish stream. Rapp P-V Réun Cons Int Explor Mer 174:3240

Rossi R, Villani P (1980) A biological analysis of eel catches, Anguilla anguilla L., from the lagoons of Lesina and Varano, Italy. J Fish Biol 16:413-423

Siegel S, Castellan NJ Jr (1988) Nonparametric statistics for behavioral sciences, 2nd edn. McGraw-Hill, New York

Sinha V, Jones J (1966) On the sex and distribution of the freshwater eel (Anguilla anguilla). J Zool 150:371-385
Sinha V, Jones J (1967) On the age and growth of the freshwater eel (Anguilla anguilla). J Zool 153:99-117

Sloane RD (1984) Distribution, abundance, growth and food of freshwater eels (Anguilla spp.) in the Douglas River, Tasmania. Aust J Mar Freshw Res 35:325-329

Smogor RA, Angermeier PL, Gaylord CK (1995) Distribution and abundance of American eels in Virginia streams: test of null models across spatial scales. Trans Am Fish Soc 124:789-803

Sokal RR, Rohlf FJ (1995) Biometry: the principles and practice of statistics in biological research, 3rd edn. W.H. Freeman, New York

Tesch F-W (1977) The eel. Biology and management of anguillid eel. Chapman \& Hall, London

Tzeng W-N, Cheng P-W, Ling F-Y (1995) Relative abundance, sex-ratio and population structure of the Japanese eel Anguilla japonica in the Tanshui River system of northern Taiwan. J Fish Biol 46:183201

Vøllestad L, Jonsson B (1988) A 13-year study of the population dynamics and growth of the European eel Anguilla anguilla in a Norwegian river: evidence for density-dependent mortality and development of a model for predicting yield. J Anim Ecol 57:983-997

Weber M (1986) Fishing method and seasonal occurrences of glass eels (Anguilla anguilla) in the rio Minho, west coast of the Iberian Peninsula. Vie Milieu 36:243-250

Wiederholm A-M (1987) Habitat selection and interactions between three marine fish species (Gobiidae). Oikos 48:28-32 